\title{
PENGARUH MODEL PEMBELAJARAN TALKING STICK BERBANTUAN LAGU TRADISIONAL TERHADAP KOMPETENSI PENGETAHUAN IPA
}

\author{
Ni Made Asih Megita Rani ${ }^{1}$, I Ketut Ardana ${ }^{2}$, I Gusti Agung Oka Negara ${ }^{3}$ \\ 1,2,3 Jurusan Pendidikan Guru Sekolah Dasar \\ Universitas Pendidikan Ganesha \\ Singaraja, Indonesia \\ e-mail: megitarani65@yahoo.com ${ }^{1}$, kttardana@gmail.com ${ }^{2}$, Igustiagungokanegara@yahoo.co.id ${ }^{3}$
}

\begin{abstract}
Abstrak
Penelitian ini bertujuan untuk mengetahui pengaruh model pembelajaran Talking Stick berbantuan Lagu Tradisional terhadap kompetensi pengetahuan IPA siswa kelas V SD Gugus I Gusti Ngurah Rai Denpasar Barat tahun ajaran 2018/2019. Jenis penelitian ini merupakan eksperimen semu dengan desain penelitian nonequivalent control group design. Populasi dari penelitian ini siswa kelas V Gugus I Gusti Ngurah Rai yang berjumlah 11 kelas terdiri dari 385 siswa. Sampel ditentukan dengan teknik random sampling. Sampel dalam penelitian ini adalah siswa kelas VA SDN 18 Padangsambian dengan jumlah siswa 38 siswa sebagai kelompok eksperimen dan siswa kelas V SDN 17 Padangsambian dengan jumlah siswa 38 orang sebagai kelompok kontrol. Pengumpulan data kompetensi pengetahuan IPA dilakukan dengan metode tes dan instrumen yang digunakan berupa tes objektif pilihan ganda biasa. Data yang diperoleh dianalisis dengan menggunakan uji-t. Hasil analisis menunjukkan bahwa terdapat perbedaan yang signifikan model pembelajaran talking stick berbantuan lagu tradisional terhadap kompetensi pengetahuan IPA dengan pembelajaran konvensional siswa kelas V SD Gugus I Gusti Ngurah Rai Denpasar Barat tahun ajaran 2018/2019. Dengan demikian dapat disimpulkan, model pembelajaran Talking Stick berbantuan Lagu Tradisional berpengaruh terhadap kompetensi pengetahuan IPA siswa kelas V SD Gugus I Gusti Ngurah Rai Denpasar Barat Tahun Ajaran 2018/2019.
\end{abstract}

Kata-kata kunci : Talking Stick, Lagu Tradisional, kompetensi pengetahuan IPA.

\begin{abstract}
This study aims to determine the effect of the Traditional Song-assisted Talking Stick learning model on science knowledge competencies of fifth grade elementary school students in Cluster I Gusti Ngurah Rai West Denpasar academic year 2018/2019. This type of research is a quasi-experimental design with nonequivalent control group design. The population of this study were fifth grade students of Class I Gusti Ngurah Rai, which amounted to 11 classes consisting of 385 students. The sample is determined by random sampling technique. The sample in this study were fifth -A grade students of SDN 18 Padangsambian with the number of students 38 students as an experimental group and fifth grade students at SDN 17 Padangsambian with 38 students as a control group.The knowledge competency data collection of science is done by the test method and the instrument used is an ordinary multiple choice objective test. The data obtained were analyzed using the t-test.The results of the analysis show that there are significant differences in the talking stick model assisted by traditional songs on science knowledge competencies with conventional learning of fifth grade elementary school students Cluster I Gusti Ngurah Rai Denpasar West academic year 2018/2019. This is evidenced by the results of the science competency knowledge mean scores of the experimental group students that are greater than the mean of the control group which is 85.02> 75.55.Thus it can be concluded, the Traditional Song-assisted Talking Stick learning model has an effect on science knowledge competencies in fifth grade students of Elementary School cluster I Gusti Ngurah Rai West Denpasar Academic Year 2018/2019.
\end{abstract}

Keywords: Talking Stick, Traditional Song, Science knowledge competency. 


\section{Pendahuluan}

Pendidikan merupakan hak semua orang yang memiliki peran yang sangat penting sebagai wadah dalam mengembangkan potensi serta wawasan anak dalam sumber daya manusia. Dalam pelaksanaan pendidikan, pemerintah telah melakukan berbagai upaya agar memperoleh hasil yang optimal salah satunya dengan adanya perubahan dan perbaikan kurikulum. Saat ini telah diterapkannya kurikulum 2013 yang dalam penerapannya menggunakan tematik integratif yaitu mengaitkan beberapa mata pelajaran kedalam sebuah tema.

Kurikulum 2013 bertujuan untuk mengembangkan potensi peserta didik baik kemampuan sikap religius, sikap sosial, intelektual, kemampuan berkomunikasi, sikap peduli, dan partisipasi aktif dalam membangun kehidupan bangsa dan bermasyarakat yang lebih baik. Kurikulum 2013 menuntut guru memiliki kreativitas dan pola berpikir tingkat tinggi (Higher Order Thinking) dalam pelaksanaan proses pembelajaran di kelas dan siswa dituntut lebih aktif sedangkan guru sebagai fasilitator.

Salah satu kompetensi yang perlu dikembangkan adalah kompetensi IPA. Pendidikan IPA merupakan salah satu bagian dari pendidikan yang memiliki potensi besar dan peranan strategis dalam menyiapkan SDM yang berkualitas. Menurut Susanto (2013:165) "IPA merupakan salah satu mata pelajaran pokok dalam kurikulum pendidikan di Indonesia termasuk pada jenjang sekolah dasar". Pendidikan IPA merupakan salah satu bagian dari pendidikan yang memiliki potensi besar dan peranan strategis dalam menyiapkan SDM yang berkualitas. Muatan materi IPA merupakan sebuah tantangan yang harus dihadapi dan diupayakan sehingga memperoleh kedudukan sejajar dengan seluruh tahapan dalam dunia pendidikan. Kompetensi dikatakan sebagai kemampuan untuk mencapai standar lulusan yang harus dimiliki siswa. Dengan demikian, maka kompetensi berkaitan dengan hasil belajar. Salah satu kompetensi yang didapat setelah proses pembelajaran adalah penguasaan kompetensi pengetahuan. Penguasaan kompetensi pengetahuan adalah perubahan tingkah laku seseoarang dari segi kemampuan pengetahuan setelah memperoleh pengalaman belajarnya. Penguasaan kompetensi pengetahuan juga dapat dinyatakan sebagai kompetensi pada ranah kognitif yang mampu mengukur tingkat penguasaan atau pencapaian siswa dalam aspek pengetahuannya.

Berdasarkan hal tersebut hasil observasi pertama teridentifikasi masalah-masalah seperti: kurang aktifnya siswa dalam kegiatan pembelajaran, siswa yang merasa bosan, siswa yang malu serta takut dalam mengutarakan pendapat sehingga kebanyakan siswa hanya menjadi pendengar dan penerima informasi, kurangnya inovasi pembelajaran yang diterapkan, pembelajaran IPA yang dianggap sebagai pembelajaran yang sulit. Dari beberapa permasalahan tersebut guru dapat merancang sebuah model pembelajaran sebagai suatu perencanaan yang digunakan sebagai pedoman dalam perencanaan pembelajaran di kelas. Maka dari itu perlu adanya inovasi pembelajaran dengan model-model pembelajaran yang menyenangkan.

Penggunaan sebuah model pembelajaran dapat menjadikan pembelajaran menjadi lebih efektif, menyenangkan, berjalan lancar dan seluruh siswa akan bersemangat didalam mengikuti pembelajaran yang berlangsung melalui model pembelajaran kooperatif. Model pembelajaran kooperatif beragam tipe dan jenisnya, salah satu contohnya pembelajaran kooperatif yaitu Talking Stick. Model pembelajaran talking stick cocok digunakan dalam kegiatan pembelajaran seperti menjawab pertanyaan siswa secara langsung juga bermain, dimana tongkat tersebut berhenti siswa berani mengemukakan pendapatnya, agar dalam proses pembelajaran menyenangkan, agar siswa termotivasi dan proses pembelajaran menyenangkan, agar hasil yang didapatkan juga berjalan dengan baik dan lancar.

Model pembelajaran Talking Stick merupakan model pembelajaran yang mengajak siswa belajar sambil bermain sehingga proses pembelajaran menjadi menyenangkan dan siswa materi dapat tersalurkan dengan optimal. Adapun keunggulan model Talking Stick adalah melatih membaca pada siswa, dapat melatih siswa untuk memahami materi dengan cepat, Mengajarakan siswa untuk bisa mengeluarkan pendapat sendiri dan mengasah pengetahuan, 
dan pengalaman siswa. Contohnya pembelajaran yang diimbangi dengan permainan, pada saat kegiatan pembelajaran dengan menggunakan teknik permainan dapat menumbuhkan minat siswa untuk belajar. Dalam hal ini permainan yang dilakukan adalah dengan menyanyikan lagu tradisional untuk menanamkan kembali kepada siswa tentang lagu-lagu tradisional khususnya lagu tradisional Indonesia agar wawasan siswa tidak hanya sebatas lagu-lagu barat. Dengan menggunakan model pembelajaran talking stick berbantuan lagu tradisional maka peserta didik akan lebih termotivasi dan lebih bersemangat dalam belajar. Hal tersebut tentunya dapat meningkatkan hasil belajar IPA siswa tersebut.

Adapun sintak metode talking stick (Huda, 2014) adalah sebagai berikut;

a) Guru menyiapkan sebuah tongkat yang panjangnya $+20 \mathrm{~cm}$.

b) Guru menyiapkan materi pokok yang akan dipelajari kemudian memberikan kesempatan kepada para kelompok untuk membaca dan mempelajari materi pelajaran.

c) Siswa berdiskusi membahas masalah yang terdapat dalam wacana.

d) Setelah siswa selesai membaca materi pelajaran dan mempelajari isinya, guru mempersilahkan siswa untuk menutup isi bacaan.

e) Guru mengambil tongkat dan memberikan kepada salah satu siswa, setelah itu guru memberikan pertanyaan dan siswa yang memegang tongkat tersebut harus menjawabnya. Demikian seterusnya sampai sebagian untuk menjawab setiap petanyaan dari guru.

f) Guru memberikan kesimpulan.

g) Guru melakukan evaluasi/ penilaian.

h) Guru menutup pembelajaran.

Kurniasih dan Sani (2016) kelebihan model pembelajaran Talking Stick adalah a) Menguji kesiapan siswa dalam penguasaan materi pelajaran, b) Melatih membaca dan memahami dengan cepat materi yang telah disampaikan, dan c) Agar lebih giat belajar karena siswa tidak pernah tau tongkat akan sampai pada gilirannya.

Model pembelajaran mempunyai peranan penting dalam memberikan pembelajaran yang aktif, efektif dan menyenangkan didalam kelas. Selain model pembelajaran, perlu adanya media-media pembelajaran yang mendukung.

Lagu daerah atau tradisional merupakan warisan kekayaan budaya Indonesia. Hampir di setiap daerah Indonesia memiliki lagu daerah sendiri. "Lagu daerah merupakan salah satu wujud karya seni yang menjadi bagian kebudayaan yang dikenal oleh masyarakat" (Pramudita, 2016: 2). Kemudian Pramudita mengatakan bahwa "lagu daerah merupakan kekayaan budaya yang dimiliki oleh suatu daerah setempat".

Mengkolaborasikan model pembelajaran Talking Stick dengan lagu tradisional dirasa akan efektif karena dalam proses pembelajaran siswa tidak hanya belajar melainkan belajar sambil bernyanyi lagu tradisional sehingga suasana belajar menjadi menyenangkan dan tujuan dari pembelajaran dapat tercapai.

Adapun kelebihan Lagu Tradisional adalah sebagai berikut: a) Mengandung nilai-nilai kehidupan yang unik dan khas, b) Tidak membutuhkan pengetahuan musik seperti membaca dan menulis not balok, dan c) Menceritakan tentang kehidupan lingkungan atau budaya masyarakat yang sangat dipengaruhi oleh adat istiadat setempat.

Pada prinsipnya, model pembelajaran talking stick memadukan pendekatan komunikatif, integratif dan keterampilan proses untuk melatih kesiapan siswa dan saling memberikan pengetahuan. Selain itu juga model pembelajaran talking stick berbantuan lagu tradisional melatih kesiapan siswa, melatih keterampilan siswa dalam membaca dan memahami materi pelajaran dengan cepat, dan mengajak mereka terus siap dalam situasi apapun. Diharapkan model pembelajaran talking stick berbantuan lagu tradisional tepat dalam melaksanakan pembelajaran siswa, agar hasil belajar dapat tercapai optimal pada mata pelajaran IPA.

\section{Metode}

Penelitian ini merupakan jenis penelitian eksperimen semu (quasi experiment) karena tidak semua kelompok yang muncul dalam kondisi eksperimen dapat diatur dan dikontrol 
secara ketat. Rancangan eksperimen yang digunakan dalam penelitian ini adalah Nonequivalent control group design. Pada penelitian ini, terdapat dua kelompok yang dipilih sebagai kelompok eskperimen dan kelompok kontrol dalam desain Nonquivalent control group designini. Kelompok eksperimen diberikan perlakuan pembelajaran dengan menggunakan model pembelajaran talking stick menggunakan lagu tradisional, sedangkan kelompok kontrol mendapat perlakuan dengan menggunakan pembelajaran konvensional. Pada akhir penelitian kedua kelompok diberi post-test untuk mengetahui adakah perbedaan antara kelompok eksperimen dengan kelompok kontrol. Jadi pada penelitian akan memberikan perlakuan kepada kedua kelas untuk membandingkan pembelajaran mana yang dioptimalkan dalam kompetensi pengetahuan IPA. Populasi merupakan adalah wilayah generalisasi yang terdiri dari objek atau subjek yang mempunyai kualitas dan karakteristik tertentu yang ditetapkan oleh peneliti guna dipelajari kemudian ditarik kesimpulannya untuk dijadikan sebagai sumber data dalam suatu penelitian.. Populasi dalam penelitian ini adalah siswa kelas $V$ di SD Negeri yang terdapat pada Gugus I Gusti Ngurah Rai Denpasar Barat yang berjumlah 15 kelas dengan jumlah 385 siswa.

Dalam penelitian ini sampel yang dipilih adalah dua kelas, kedua kelas tersebut nantinya akan diberikan perlakukan yang berbeda. Satu kelas akan diberikan perlakuan berupa model pembelajaran talking stickmenggunakanlagu tradisional dan satu kelas lagi diberikan perlakuan dengan menggunakan pendekatan konvensional.Teknik pengambilan sampel yang digunakan dalam penelitian ini adalah teknik random sampling. Teknik random sampling dilaksanakan dengan mengacak subjek-subjek di dalam populasi, sehingga semua subjek dianggap sama dan mendapat hak yang sama untuk memperoleh kesempatan dipilih menjadi anggota sampel. Pengacakan yang dilakukan adalah acak kelas kemudian dilakukan pengundian. Sampel yang dirandom dalam penelitian ini adalah kelas karena dalam eksperimen tidak memungkinkan untuk mengubah kelas yang ada. Kelas dipilih sebagaimana telah terbentuk tanpa campur tangan peneliti. Sampel yang dipilih yakni dua kelas,satu kelas sebagai kelompok eksperimen yang diberikan perlakuan dengan menerapkan model pembelajaran talking stick berbantuan lagu tradisional dan satu kelas sebagai kelompok kontrol yang dibelajarkan secara konvensional. Kedua kelompok tersebut disetarakan secara akademik dengan diberikan pretest. Setelah kedua kelompok dinyatakan setara, selanjutnya dilakukan pengundian untuk menentukan kelompok eksperimen dan kelompok kontrol. Sehingga kedua kelompok tersebut dijadikan sampel penelitian.

Instrumen yang digunakan untuk mengukur kompetensi pengetahuan IPA adalah tes pilihan ganda biasa. Menurut Sugiyono (2016:102) "instrumen penelitian adalah suatu alat ukur yang digunakan dalam penelitian". Instrumen dari penelitian ini digunakan untuk mengukur kompetensi pengetahuan IPA siswa pada kedua kelas yang diberikan perlakuan berbeda yaitu kelas yang menggunakan model pembelajaran takling stick berbantuan lagu tradisionaldan kelas yang menggunakan pembelajaran konvensional. Tes yang diberikan untuk kedua kelas tersebut pada akhir perlakuan akan digunakan untuk menguji kebenaran hipotesis penelitian. Tes pilihan ganda biasa ini meliputi 4 pilihan jawaban ( $a, b, c$, atau d) dengan jumlah pertanyaan yaitu 50 butir soal. Setiap item diberikan skor 1 bila siswa menjawab benar, disesuaikan dengan kunci jawaban, dan skor 0 bila siswa menjawab salah. Sebelum memberikan tes kepada siswa, terlebih dahulu menguji kelayakan instrumen tes yang akan digunakan untuk mengukur pemahaman konsep IPA.

Analisis data dilakukan dengan analisis deskriptif dan analisis inferensial. Statistik deskriptif merupakan statistik yang mempelajari tentang cara mengumpulkan dan menyajikan data sehingga mudah dipahami oleh peneliti.Statistik deskriptif dimaksud untuk menentukan rata-rata mean, median, modus, standar deviasi, varian nilai minimum, nilai maksimum rentangan, panjang kelas, banyak kelas dan presentase rata-rata dari masing-masing kelompok. Menurut Agung (2016:3) statistik inferensial merupakan "Bidang ilmu statistika yang mempelajari tentang tata cara penarikan kesimpulan-kesimpulan mengenai keadaan populasi, berdasarkan hasil analisis data terhadap bagian dari populasi yang disebut sampel". Untuk menjawab rumusan dan menguji hipotesis digunakan uji t. Sebelum dilakukan uji hipotesis terlebih dahulu dilakukan uji prasyarat analisis data seperti Uji normalitas dilakukan untuk 
mengetahui apakah uji hipotesis dengan statistik parametrik bisa dilakukan atau tidak. Apabila sebaran data sudah berdistribusi normal, maka uji lanjut dengan menggunakan statistik parametrik bisa dilakukan. Sebaliknya, bila data tidak berdistribusi normal maka uji lanjut dengan menggunakan statistik non parametrik.Untuk mengetahui apakah sebaran data skor hasil belajar siswa masing-masing kelompok berdistribusi normal atau tidak, digunakan analisis Chi-Kuadrat. Selanjutnya uji homogenitas dilakukan untuk menunjukkan bahwa perbedaan yang terjadi pada uji hipotesis benar-benar terjadi akibat adanya perbedaan antar kelompok, bukan malah akibat dari adanya perbedaan dalam kelompok. Uji Homogenitas varians untuk kedua kelompok digunakan uji F. Data yang telah diuji normalitas dan homogenitasnya maka akan diuji hipotesisnya. Uji Hipotesis menggunakan uji-t dengan rumus polled varians. Rumus uji-t dengan rumus polled varians digunakan bila jumlah anggota sampel sama $n 1=n 2$ dan varians homogen. Dengan kriteria pengujian jika thitung $>$ ttabel, sehingga $\mathrm{HO}$ ditolak dan $\mathrm{Ha}$ diterima. Pada taraf signifikan $5 \%(\alpha=0,05)$ dengan $d k n 1+n 2-2$.

\section{Hasil dan Pembahasan}

Penelitian ini menujukkan bahwa kompetensi pengetahuan IPA siswa yang dicapai dengan menggunakan model pembelajaran talking stick berbantuan lagu tradisional terdapat perbedaan dengan siswa yang belajar dengan menggunakan pembelajaran konvesional. Data hasil penguasaan kompetensi pengetahuan IPA diperoleh dari hasil posttest yang diberikan pada akhir penelitian. Kelompok eksperimen yang digunakan dalam penelitian ini yaitu kelas V/A SDN 18 Padangsambian berjumlah 38 siswa, sedangkan kelompok kontrol adalah kelas V SDN 17 Padangsambian berjumlah 387 siswa. Instrumen yang digunakan untuk mengumpulkan data adalah tes objektif pilihan ganda biasa. Rancangan penelitian yang digunakan dalam penelitian ini adalah Nonequivalent control group design dengan menggunakan uji-t sebagai alat untuk menganalisis data. Deskripsi data hasil penguasaan kompetensi pengetahuan IPA siswa yang dipaparkan meliputi nilai rerata, varians, dan standar deviasi. Kelas V/A SDN 18 Padangsambian ditetapkan sebagai kelompok eksperimen yang diberi perlakuan berupa pengaruh model pembelajaran Talking Stick berbantuan Lagu Tradisional sebanyak 6 kali pertemuan, kemudian diberikan posttest untuk memperoleh hasil penguasaan kompetensi pengetahuan IPA siswa. Data hasil penguasaan kompetensi pengetahuan IPA diperoleh dari hasil posttest yang diberikan pada akhir penelitian. Instrumen yang digunakan untuk mengumpulkan data adalah tes objektif pilihan ganda biasa. Deskripsi data hasil penguasaan kompetensi pengetahuan IPA siswa yang dipaparkan meliputi nilai rerata, varians, dan standar deviasi.

Tabel 1. Hasil Pengolahan Data Post-test Kelompok Eksperimen dan Kontrol

\begin{tabular}{lcl}
\hline Statistik & Kelompok Eksperimen & Kelompok Kontrol \\
\hline Mean & 85,02 & 75,55 \\
Rerata Persentase & $85,02 \%$ & $75,55 \%$ \\
Varians & 60,60 & 49,19 \\
Standar Deviasi & 7,78 & 7,01 \\
Skor Minimum & 70 & 60 \\
Skor Maksimum & 100 & 100 \\
\hline
\end{tabular}

Berdasarkan hasil analisis statistik kompetensi pengetahuan IPA siswa yang dibelajarkan menggunakan model pembelajaran talking stick berbantuan Lagu tradisional di peroleh $\overline{\mathrm{x}}=$ 85,02 dan standar deviasi $=7,78$ sedangkan statistik kompetensi pengetahuan IPA siswa yang dibelajarakan menggunakan pembelajaran konvensional di peroleh $\overline{\mathrm{X}}=75,55$ dengan standar deviasi $=7,01$. Dari data tersebut menunjukan bahwa kompetensi pengetahuan kelompok yang dibelajarkan melalui model talking stick berbantuan lagu tradisional memiliki rata-rata yang lebih tinggi dari kelompok yang dibelajarkan melalui pembelajaran konvensional. 
Sebelum dilakukan pengujian hipotesis dengan analisis uji-t, terlebih dahulu dibutuhkan data yang berdistribusi normal dan homogen. Maka dari itu, perlu dilakukan uji normalitas sebaran data dan uji homogenitas varians untuk memenuhi prasyarat yang dibutuhkan untuk menggunakan teknik analisis uji -t ( $t$-test).

Berdasarkan hasil uji normalitas kelompok eksperimen, diperoleh Chi Kuadrat hitung $\left(x^{2}\right.$ hitung $\left.=4,886\right)$ kemudian nilai tersebut dibandingkan dengan Chi Kuadrat tabel $\left(x^{2}\right.$ tabel $\left.=11,07\right)$. $\mathrm{Hal}$ ini menunjukkan bahwa $\mathrm{x}^{2}{ }_{\text {hitung }}<\mathrm{x}^{2}$ tabel berarti data hasil penguasaan kompetensi pengetahuan IPA kelompok eksperimen berdistribusi normal.

Berdasarkan hasil uji normalitas kelompok kontrol, diperoleh Chi Kuadrat hitung $\left(\mathrm{x}^{2}\right.$ hitung $=$ $4,632)$ kemudian nilai tersebut dibandingkan dengan Chi Kuadrat tabel $\left(x^{2}\right.$ tabel $\left.=11,07\right)$. Hal ini menunjukkan bahwa $x^{2}$ hitung $<x^{2}$ tabel berarti data hasil penguasaan kompetensi pengetahuan IPA kelompok kontrol berdistribusi normal.

Uji homogenitas dapat dilakukan apabila kelompok data tersebut dalam distribusi normal. Uji homogenitas varians menggunakan uji $F$. Apabila $F_{\text {hitung }}<F_{\text {tabel, }}$, maka sampel homogen. Pengujian dilakukan pada taraf signifikan $5 \%$ dengan derajat kebebasan( $\mathrm{dk}_{1}$ ) untuk pembilang $\mathrm{n}_{1}-1$ dan derajat kebebasan $\left(\mathrm{dk}_{2}\right)$ untuk penyebut $\mathrm{n}_{2}-1$. Hasil analisis uji $\mathrm{F}$ disajikan dalam tabel 2.

Tabel 2. Uji Homogenitas Varians

\begin{tabular}{lccccl}
\hline \multicolumn{1}{c}{ Sampel } & Standar Deviasi $(\mathrm{s})$ & Varians $\left(\mathrm{S}^{2}\right)$ & $F_{\text {hitung }}$ & $F_{\text {tabel }}$ & Status \\
\hline Kelompok Eksperimen & 7,78 & 60,60 & \multirow{2}{*}{1,23} & \multirow{2}{*}{1,71} & Homogen \\
Kelompok Kontrol & 7,01 & 49,19 & & & \\
\hline
\end{tabular}

Dari hasil analisis, diperoleh $\mathrm{F}_{\text {hitung }}<\mathrm{F}_{\text {tabel }}$, sehingga varians antara kelompok siswa yang dibelajarkan melalui model pembelajaran talking stick berbantuan Lagu tradisional dan kelompok siswa yang dibelajarkan melalui pembelajaran konvensional memiliki varians yang homogen.

Hipotesis yang di uji adalah $\mathrm{H}_{0}$ yang berbunyi Tidak terdapat pengaruh yang signifikan model Pembelajaran Talking Stick berbantuan Lagu Tradisional terhadap Kompetensi Pengetahun IPA pada Kelas V SD Gugus I Gusti Ngurah Rai Denpasar Barat Tahun Ajaran 2018/2019. Berdasarkan hasil uji normalitas dan uji homogenitas varians diperoleh data kedua kelompok yaitu kelompok siswa yang dibelajarkan menggunakan model pembelajaran Talking Stick berbantuan Lagu Tradisional dan kelompok siswa yang dibelajarkan menggunakan model pembelajaran konvensional berdistribusi normal dan varians kedua kelompok homogen. Berdasarkan hal itu maka uji statistik yang digunakan dalam penelitian ini adalah uji beda mean (Uji-t) dengan rumus Polled Varians. Dengan kriteria pengujian jika $t_{\text {hitung }}<t_{\text {tabel }}$ maka $H_{0}$ diterima dan $\mathrm{H}_{\mathrm{a}}$ ditolak, dan jika harga $\mathrm{t}_{\text {hitung }}>\mathrm{t}_{\text {tabel, }}$ Maka $\mathrm{H}_{0}$ ditolak dan $\mathrm{H}_{\mathrm{a}}$ diterima. Pada taraf signifikan $5 \%(\alpha=0,05)$ dengan $\mathrm{dk}=\mathrm{n} 1+\mathrm{n} 2-2$. Hasil perhitungan uji hipotesis disajikan dalam tabel berikut.

Tabel 3. Uji hipotesis

\begin{tabular}{lllllllll}
\hline No & Sampel & $\mathrm{N}$ & $\mathrm{dk}$ & Mean & Varians & $\mathrm{t}_{\text {hitung }}$ & $\mathrm{t}_{\text {tabel }}$ & Kesimpulan \\
\hline 1 & Eksperimen & 38 & 76 & 82,02 & 60,60 & 5,70 & 2,000 & $\mathbf{H}_{\mathrm{o}}$ ditolak \\
2 & Kontrol & 38 & & 75,55 & 49,19 & & & \\
\hline
\end{tabular}

Berdasarkan tabel diatas, dapat dilihat bahwa $t_{\text {hitung }}$ lebih besar dari pada $t_{\text {tabel }}$ yaitu 5,70 > 2,000. Dengan hasil tersebut maka dapat disimpulkan bahwa $\mathrm{H}_{0}$ yang berbunyi "Tidak terdapat perbedaan yang signifikan kompetensi pengetahuan IPA antara kelompok siswa yang dibelajarkan menggunakan model pembelajaran Talking Stick berbantuan Lagu Tradisional dan kelompok siswa yang dibelajarkan menggunakan model pembelajaran konvensional pada 
siswa kelas V SD Gugus I Gusti Ngurah Rai Denpasar Barat Tahun Ajaran 2018/2019", ditolak.

Ha yang menyatakan "Terdapat perbedaan yang signifikan kompetensi pengetahuan IPA antara kelompok siswa yang dibelajarkan menggunakan model pembelajaran Talking Stick berbantuan Lagu Tradisional dan kelompok siswa yang dibelajarkan menggunakan model pembelajaran konvensional pada siswa kelas V SD Gugus I Gusti Ngurah Rai Denpasar Barat Tahun Ajaran 2018/2019", diterima

Berdasarkan hasil uji hipotesis diperoleh $t_{\text {hitung }}=5,70$ sedangkan pada taraf signifikan $5 \%$ dan $\mathrm{dk}=76$ diperoleh $\mathrm{t}_{\text {tabel }}=2,000$ sehingga $t_{\text {hitung }}=5,70>t_{\text {tabel }}=2,000$. Dengan demikian, hipotesis nol $\left(\mathrm{H}_{0}\right)$ ditolak. Hal ini berarti terdapat perbedaan yang signifikan penguasaan kompetensi pengetahuan IPA antara siswa V SD Gugus I Gusti Ngurah Rai Denpasar Barat Tahun Ajaran 2018/2019 yang mengikuti pembelajaran menggunakan model pembelajaran Talking Stick berbantuan Lagu Tradisional dan siswa yang menggunakan model pembelajaran konvensional. Perolehan hasil perhitungan analisis data yang dilakukan menunjukan bahwa nilai rata-rata siswa yang mengikuti pembelajaran menggunakan model Talking Stick berbantuan Lagu Tradisional $(\bar{X}=85,02)$ dan siswa yang mengikuti pembelajaran konvensional $(\bar{X}=75,55)$ memiliki perbedaan selisih 9,47 . Dengan demikian, terdapat pengaruh penguasaan kompetensi pengetahuan IPA antara siswa kelas V di SD Gugus I Gusti Ngurah Rai Denpasar Barat Tahun Ajaran 2018/2019 yang mengikuti pembelajaran menggunakan model pembelajaran Talking Stick berbantuan Lagu Tradisional dan siswa yang mengikuti pembelajaran konvensional.

Pada kelompok eksperimen kegiatan pembelajaran dalam muatan materi IPA menggunakan model pembelajaran Talking Stick berbantuan Lagu Tradisional berjalan dengan kondusif dan menyenangkan. Hal ini disebabkan oleh model pembelajaran Talking Stick berbantuan Lagu Tradisional merupakan suatu model pembelajaran yang mengajak siswa belajar sambil bermain dimana didalam pembelajaran siswa diharapkan saling bekerja sama serta aktif berkelompok. Dan dengan berbantuan lagu tradisional siswa dapat belajar sambil bernyanyi lagu tradisional sehingga suasana belajar menjadi menyenangkan dan tujuan dari pembelajaran dapat tercapai.

Berbeda dengan kelompok kontrol, kegiatan pembelajaran konvensional yang hanya menggunakan pendekatan saintifik berjalan kurang optimal. Hal ini disebabkan siswa yang kurang mampu mengaitkan antar materi pada muatan materi IPA dan kesulitan mengikuti setiap langkah pembelajaran yang perlu diberikan bimbingan lebih khusus. Pembelajaran menggunakan model pembelajaran Talking Stick berbantuan Lagu Tradisional pada pembelajaran IPA memberikan kesempatan yang lebih luas kepada siswa untuk mengonstruksikan pengetahuannya melalui berbagai kegiatan bermakna dan teratur yang tentunya menyenangkan bagi siswa pada setiap langkah pembelajarannya. Dengan demikian, perbedaan hasil penguasaan kompetensi pengetahuan IPA dapat terlihat dari langkah pembelajaran yang dilakukan pada kedua kelompok tersebut, hasil analisis uji hipotesis, dan nilai rerata kelompok siswa yang mengikuti pembelajaran menggunakan model pembelajaran Talking Stick berbantuan Lagu Tradisional dengan siswa yang mengikuti pembelajaran konvensional.

\section{Simpulan dan Saran}

Kompetensi pengetahuan IPA siswa yang dibelajarkan melalui model pembelajaran Talking Stick berbatuan lagu Tradisional pada kelompok eksperimen sebesar 85,02 dengan nilai tertinggi yang diperoleh siswa adalah 97 dan nilai terendah 70 . Kompetensi pengetahuan IPA siswa yang dibelajarkan melalui pembelajaran konvensional pada siswa kelompok kontrol sebesar 75,55 dengan nilai tertinggi yang diperoleh siswa adalah 90 dan nilai terendah 60 .

Rerata kometensi pengetahuan IPA yang diperoleh antara siswa yang dibelajarkan model pembelajaran Takling Stick berbantuan Lagu Tradisional $=85,02$ dan siswa dengan pembelajaran konvensional $=75,55$ dan ditunjukkan hasil analisis hipotesis $:$ thitung $>$ ttabel 
$(5,70>2,000)$ ) pada taraf signifikansi $5 \%$ dengan $\mathrm{dk}=74$, dengan demikian terdapat perbedaan yang signifikan Kompetensi Pengetahuan IPA siswa yang dibelajarkan model pembelajaran Talking Stick berbantuan Lagu tradisional dengan siswa yang pembelajaran Konvensional Kelas V pada Gugus I Gusti Ngurah Rai Denpasar Barat Tahun Ajaran 2018/2019. Hal tersebut menyatakan bahawa terdapat pengaruh Model Pembelajaran Talking Stick berbantuan Lagu Tradisional terhadap kompetensi pengetahuan IPA kelas V SD Gugus I Gusti Ngurah Rai Denpasar Barat Tahun Ajaran 2018/2019.

\section{Daftar Pustaka}

Adnyana, Wira Surya. 2017. "Pengaruh Model Pembelajaran Kooperatif Talking Stick Terhadap Kompetensi Pengetahuan IPA Siswa Kelas V SD Gugus Kapten Kompyang Sujana". Universitas Pendidikan Ganesha. Volume 5 nomor 3. (Diakses pada tanggal 1 Februari 2019).

Agung, 2016. Statistik Dasar untuk Pendidikan. Yogyakarta: Deepublish.

Aqib, Zainal. 2013. Model-model,Media,dan Strategi Pembelajaran Kontekstual (Inovatif). Bandung: Yrama Widya.

Arikunto, Suharsimi. 2013. Dasar-dasar Evaluasi Pendidikan. Jakarta: Bumi Aksara

Astuti, Ni Kadek Sri. 2017."Pengaruh Model Pembelajaran Talking Stick Berbasis Concept Song Terhadap Kompetensi Pengetahuan IPA Siswa Kelas V SD Gugus Budi Utomo Denpasar Timur Tahun Ajaran 2016/2017". Universitas Pendidikan Ganesha. Volume 5 nomor 2. (Diakses pada tanggal 1 Februari 2019).

Dantes, Nyoman. 2012. Metode Penelitian . Yogyakarta: Andi Offset.

Darmadi, Hamid. 2013. Dimensi-dimensi Metode Penelitian Pendidikan dan Sosial. Bandung: Alfabeta.

Hasan, Iqbal. 2008. Analisis Data Penelitian dengan Statistik. Jakarta: Bumi Aksara.

Huda, Miftahul. 2014. Model-Model Pengajaran dan Pembelajaran. Yogyakarta :Pustaka Pelajar.

Kemendikbud. 2014. Permendikbud No. 103 Tahun 2014 tentang Pembelajaran Pada Pendidikan Dasar dan Pendidikan Menengah . Jakarta: Kementerian Pendidikan dan Kebudayaan RI.

Kosasih. 2014. Strategi Belajar dan Pembelajaran. Bandung: Yrama Widya.

Kurniasih, Imas dan Berlin Sani. 2016. Ragam Pengembangan Model Pembelajaran untuk Peningkatan Profesionalitas Guru. Surabaya : Kata Pena.

Lestari, Ni Ketut Trianti. 2017. "Pengaruh Model Pembelajaran Talking Stick Berbantuan Lagu Daerah Terhadap Hasil Belajar IPS". Universitas Pendidikan Ganesha. Volume 1 nomor 4. (Diakses pada tanggal 1 Februari 2019).

Pramudita, Meylana. 2016. Pembelajaran Lagu Daerah Dalam Menanamkan Apresiasi Siswa Kelas V Di SD 3 Blimbing Kidul Kabupaten Kudus. Universitas Negeri Semarang. (Diakses pada tanggal 1 Februari 2019). 
Samatowa, Usman. 2011. Pembelajaran IPA di Sekolah Dasar. Jakarta: PT Indeks.

Setyosari, Punaji. 2015. Metode Penelitian Pendidikan \& Pengembangan, Jakarta :Kharisma Putra Utama.

Sudijono, Anas. 2012. Pengantar Evaluasi Pendidikan, Jakarta : Raja Grafindo Persada.

Sugiyono. 2010. Statistika untuk Penelitian. Bandung: Alfabeta.

Sugiyono. 2014. Metode Penelitian Pendidikan Pendekatan kuantitatif kualitatif,dan R\&D. Bandung: Alfabeta .

Sugiyono. 2016. Metode Penelitian Kuantitatif, Kualitatif,dan R\&D . Bandung: Alfabeta.

Sukardi. 2007. Metodelogi Penelitian Pendidikan Kompetensi dan Praktiknya. Jakarta :Bumi Aksara.

Susanto, Ahmad. 2013. Teori Belajar dan Pembelajaran di Sekolah Dasar, Jakarta : Kharisma Putra Utama.

Widoyoko, Eko Putro. 2013. Evaluasi Program Pembelajaran.Yogyakarta: Pustaka Pelajar 